\title{
Medicinal plants used in the phytotherapeutical treatment of urolithiasis in dogs - na
}

\section{integrative review}

\author{
Plantas medicinais utilizadas no tratamento fitoterapêutico da urolitíase em cães - uma revisão \\ integrativa
}
Plantas medicinales utilizadas en el tratamiento fitoterapéutico de la urolitiasis en perros - una revisión integradora

Received: 09/21/2021 | Reviewed: 09/26/2021 | Accept: 09/27/2021| Published: 09/28/2021

\author{
Camila Oliveira Rocha \\ ORCID: https://orcid.org/0000-0002-7783-2476 \\ Universidade Federal do Triâgulo Mineiro, Brazil \\ E-mail: camilarochavet@gmail.com \\ Ana Claudia Granato \\ ORCID: https://orcid.org/0000-0001-6487-1225 \\ Universidade Federal do Triâgulo Mineiro, Brazil \\ E-mail: ana.malpass@uftm.edu.br
}

\begin{abstract}
Urolithiasis is a disease in which uroliths form in the urinary tract from individual predisposing factors of each species, and with aggravation, animals can have urethral obstruction and die. In this work, an integrative review of the medicinal plants most used for the treatment of urolithiasis in dogs was carried out. The objective of this work is to collaborate with the veterinary community to expand the use of herbal medicine to treat this pathology, mainly due to its relapsing nature. Its formation can occur in breeds with more evident urinary supersaturation, genetic predisposition, age, reduced daily water intake, metabolic problems, medications that alter urinary $\mathrm{pH}$, inadequate nutrition and predisposition to alterations in the urinary tract. Drug and nutritional treatment is questionable, as there are types of differences in the composition of stones and the response to these can vary a lot and, in more serious cases, surgery is needed. At high rates of recurrence, the use of medicinal plants offers options aimed at the welfare of animals. Therefore, innovative research on their use of these plants informs how they can be consumed safely and with great pharmacological effect. With this, more tutors are looking for professionals who prescribe these plants in a preventive way, avoiding surgical emergencies and possible death of your animal. Urinary system herbal medicines control inflammation and increase diuresis, preventing crystal aggregation and possible growth, in addition to favoring their elimination through the urethra.
\end{abstract}

Keywords: Phitoterapy; Medicinal plants; Urolitiasis; Dogs.

\section{Resumo}

A urolitíase é uma enfermidade na qual urólitos se formam no trato urinário a partir de fatores predisponentes individuais de cada espécie e com agravamento os animais podem ter obstrução da uretra e vir a óbito. Neste trabalho foi feita uma revisão integrativa sobre as plantas medicinais mais utilizadas para o tratamento de urolitíase em cães. O objetivo deste trabalho é colaborar com a comunidade veterinária para ampliação do uso da fitoterapia para tratar essa patologia, principalmente pelo seu caráter recidivante. A sua formação pode ocorrer em raças com superssaturação urinária mais evidente, predisposição genética, idade, ingestão hídrica diária diminuída, problemas metabólicos, medicações que alterem o pH urinário, nutrição inadequada e predisposição a alterações do trato urinário. $\mathrm{O}$ tratamento medicamentoso e nutricional é questionável, pois há tipos diferenças na composição das pedras e a resposta a esses pode variar muito e, em casos mais sérios, há necessidade de cirurgia. Às altas taxas de recidiva, a utilização de plantas medicinais oferece opções voltadas ao bem-estar dos animais. Portanto, as pesquisas inovadoras sobre a sua utilização dessas plantas informam como elas podem ser consumidas de forma segura e com ótimo efeito farmacológico. Com isso, mais tutores buscam profissionais que prescrevam de forma preventiva essas plantas, evitando emergências cirúrgicas e possível morte do seu animal. Os fitoterápicos do sistema urinário controlam a inflamação, e aumentam a diurese evitando a agregação dos cristais e possível crescimento, além de favorecer a eliminação dos mesmos pela uretra.

Palavras-chave: Fitoterapia; Plantas medicinais; Urolitíase; Cães. 


\begin{abstract}
Resumen
La urolitiasis es una enfermedad en la que se forman urolitos en el tracto urinario a partir de factores predisponentes individuales de cada especie y, con agravamiento, los animales pueden tener obstrucción uretral y morir. En este trabajo se realizó una revisión integradora de las plantas medicinales más utilizadas para el tratamiento de la urolitiasis en perros. El objetivo de este trabajo es colaborar con la comunidad veterinaria para ampliar el uso de la fitoterapia en el tratamiento de esta patología, principalmente por su naturaleza recidivante. Su formación puede ocurrir en razas con más evidente sobresaturación urinaria, predisposición genética, edad, disminución de la ingesta diaria de agua, problemas metabólicos, medicamentos que alteran el pH urinario, nutrición inadecuada y predisposición a alteraciones en el tracto urinario. El tratamiento farmacológico y nutricional es cuestionable, ya que existen tipos de diferencias en la composición de los cálculos y la respuesta a estos puede variar mucho y, en casos más graves, es necesaria la cirugía. A altas tasas de recurrencia, el uso de plantas medicinales ofrece opciones dirigidas al bienestar de los animales. Por lo tanto, la investigación innovadora sobre el uso de estas plantas informa cómo se pueden consumir de manera segura y con un gran efecto farmacológico. Con esto, más tutores buscan profesionales que prescriban estas plantas de forma preventiva, evitando emergencias quirúrgicas y la posible muerte de tu animal. Las hierbas medicinales del sistema urinario controlan la inflamación y aumentan la diuresis, evitando la agregación de cristales y su posible crecimiento, además de favorecer su eliminación a través de la uretra.
\end{abstract}

Palabras clave: Fitoterapia; Plantas medicinales; Urolitiasis; Perros.

\title{
1. Introduction
}

The word phytotherapy is derived from the Greek phyton and therapeia, which means treatment using plants, referring to the use of medicinal plants in the cure of illnesses (Guedes et al., 2016). These are drugs acquired through plant raw materials or even their active principles and thus act in the recovery of diseases or in the attenuation of their clinical symptoms, and their efficacy and safety are validated by clinical trials, that are supervised by ANVISA (Agency National Health Surveillance) and through published scientific documentation (Teixeira \& Santos, 2011). Evidence exists that there are advantages in the treatment with medicinal plants, such as the cost-benefit ratio due to great biodiversity and the pharmacological action with low adverse and toxic effects.

Worldwide, medicinal plants have been used to control urolithiasis. With the aim of advancing research in this area, the determination of its effectiveness through the development of clinical studies has proven the effectiveness of this therapy for the control of diseases. Urolithiasis brings clinical discomfort to the animals, frequently requiring treatment in cases of malaise and complications in cases of urinary infections and obstruction. Accuracy in diagnosis is an essential factor for effective treatment and, therefore, the detection of the type of urolith is important. Therefore, the treatment must be carried out according to the main factors of appearance of each specific urolith (Cruces et al., 2013).

An example of this is the saturation of urine by solutes and the formation and aggregation of crystals. Therefore, the variable response to different treatments (medical and nutritional), and the high rates of recurrence are also complicating factors in managing the condition. Regarding nutrition, changes that an apply a natural diet or feed can cause a change in urinary composition, increasing the solubilization of urinary crystals (Singh et al., 2011). The pharmacological treatment aims at changing the urinary $\mathrm{pH}$ to also help in the solubilization of pre-formed crystals. Meanwhile, the most indicated treatment in complicated cases is patient stabilization and referral for surgery, but the animal can still relapse as the underlying problem has not been resolved (Lulich et al.,2008). Thus, to avoid animal suffering and mortality with aggravation of the pathology, herbal medicine has become a choice for the well-being and prolonged quality of life of animals (Berent, 2015; Raditic, 2015).

Prevention is still the preferred option in this situation and using medicinal plants for this purpose can help reduce urinary tract inflammation and increase diuresis to prevent crystals from forming a main nucleus and growing, in addition to expelling the lower uroliths due to increased urination. The individualization of each clinical case is carried out by nutritional monitoring, blood tests, urinalysis, and ultrasonography at least every 3 months with necessary modifications for severe cases (which can be performed every month) and for maintenance every six months to a year.

The main objective of this article was to perform an integrative review of the medicinal plants used to treat urolithiasis 
in dogs. As methodology, the integrative review was chosen (Pereira et al., 2018). According to Souza; Silva \& Carvalho (2010) an integrative review is a broad methodological approach that anlyzes experimental and non-experimental studies to understand a given phenomenon, combining data from theoretical and empirical literature, and defining concepts. To develop this integrative review, articles were selected using the following databases: Web of Science, Pubmed, Google Scholar, Lilacs and Scielo. The selected references are available at the consulted databases and were published between the years 2005 and 2021. The keywords used for the searches were: Urinary calculus in dogs, Herbal medicine in dogs, Veterinary herbal medicine, lithiasis in dogs, medicinal plants, canine urolithiasis, dog urolithiasis, urinary system physiology in dogs. The criterion for the selection of articles was that they should contain the keywords used in the title or abstract. Some articles older than the mentioned period were used to provide basic knowledge and information that was not found in the articles found in the period under study.

\section{Urolithiasis}

Urolithiasis is the formation of urinary stones from less soluble crystals in urine. These macroscopic sediments and macroscopic precipitates are called uroliths and can be formed under pathological and physiological conditions. It is a common problem in dogs and can occur anywhere in the urinary tract (UT), although they are more common in the bladder (Waki Kogika, 2015).

The main etiology is the relationship of the change in urinary $\mathrm{pH}$ and, consequently, this acid-base imbalance permits the precipitation of crystals according to each specification of uroliths, even with this individualization, it is important to highlight that the ideal reference values for urinary pH of dogs is from 5 to 7 (Rodrigues, 2021). Other causes would be the presence of hereditary, congenital, or acquired diseases that lead to an increase in the elimination of minerals in the urine. Table 1 presents a summary of the main uroliths and their specifications for appearance are described.

Regarding the physiology of the urinary tract defense mechanisms, the most influential ones are related to the pathogenesis of UTI, where more complicated cases may be related to errors in the animal's defense mechanisms that interfere with normal urination, anatomical problems, damage to mucosal barriers and even changes in urinary quantity and/or composition (Grauer, 2012). 
Table 1. Different types of uroliths and their specifications.

\begin{tabular}{|c|c|c|c|c|c|c|c|}
\hline & STRUVITE & $\begin{array}{l}\text { CALCIUM } \\
\text { OXALATE }\end{array}$ & $\begin{array}{c}\text { URATE } \\
\text { (Produced by } \\
\text { purine metabolism) }\end{array}$ & $\begin{array}{l}\text { CALCIUM } \\
\text { PHOSPHATE }\end{array}$ & CISTINE & SILICA & $\begin{array}{c}\text { XANTINE } \\
\text { (Produced by } \\
\text { purine } \\
\text { metabolism and } \\
\text { prolonged } \\
\text { allopurinol use) }\end{array}$ \\
\hline urinary pH & Neutral-alkaline & Neutral-acid & Neutral-acid & Neutral-alkaline & Neutral-acid & Neutral-acid & Neutral-acid \\
\hline Crystal Aspects & $\begin{array}{l}\text { Colorless prisms from } \\
4 \text { to } 6 \text { sides }\end{array}$ & $\begin{array}{c}\text { Dihydrated salt, } \\
\text { octahedral or } \\
\text { envelope format, } \\
\text { colorless; dumbbell } \\
\text { or spindle shape of } \\
\text { the monohydrated } \\
\text { salt }\end{array}$ & $\begin{array}{l}\text { Amorphous or } \\
\text { spherical shape } \\
\text { (ammonium urate) } \\
\text { yellow-brown }\end{array}$ & $\begin{array}{l}\text { Amorphous or long } \\
\text { slender cousins }\end{array}$ & $\begin{array}{l}\text { Flat, hexagonal, } \\
\text { colorless and flat } \\
\text { blades }\end{array}$ & None observed & -- \\
\hline Urinary culture & Urease + Bacteria & Negative & Negative & $\begin{array}{c}\text { Negative } \\
\text { (can influence) }\end{array}$ & Negative & Negative & negative \\
\hline Seric alterations & None & $\begin{array}{c}\text { Occasional } \\
\text { Hypercalcemia }\end{array}$ & $\begin{array}{l}\text { Low urea nitrogen } \\
\text { and serum albumin - } \\
\text { portosystemic bypass }\end{array}$ & $\begin{array}{c}\text { Occasional } \\
\text { Hypercalcemia }\end{array}$ & None & None & -- \\
\hline $\begin{array}{l}\text { Predisposing } \\
\text { Races }\end{array}$ & $\begin{array}{l}\text { Schnauzer, } \\
\text { Bichon Frise, } \\
\text { Cocker Spaniel } \\
\text { Lhasa Apso }\end{array}$ & $\begin{array}{c}\text { Schnauzer } \\
\text { Lhasa Apso, } \\
\text { Yorkshire Terrier, } \\
\text { Poodle } \\
\text { Shih Tzu, } \\
\text { Bichon Frise }\end{array}$ & $\begin{array}{c}\text { Dalmation, } \\
\text { English Bulldog, } \\
\text { Schanuzer } \\
\text { Yorkshire Terrier }\end{array}$ & $\begin{array}{l}\text { Yorkshire Terrier, } \\
\text { Schanuzer } \\
\text { Cocker Spaniel }\end{array}$ & $\begin{array}{l}\text { English Bulldog } \\
\text { Daschshund } \\
\text { Basset Hound }\end{array}$ & $\begin{array}{l}\text { German Shepard, } \\
\text { Golden Retriever, } \\
\text { Labrador, } \\
\text { Schnauzer }\end{array}$ & $\begin{array}{l}\text { Cavalier King } \\
\text { Charles Spaniel. }\end{array}$ \\
\hline Age & Any age & 5-11 years & 3-6 years & $7-12$ anos & $3-8$ years & $3-10$ years & -- \\
\hline $\begin{array}{c}\text { Sexual } \\
\text { predisposition }\end{array}$ & Females $(>85 \%)$ & Males (>70\%) & Males (>85\%) & Males (>53\%) & Males (94\%) & Males (92\%) & Males \\
\hline $\begin{array}{l}\text { Radiographic } \\
\text { contour }\end{array}$ & $\begin{array}{l}\text { Smooth, round, or } \\
\text { faceted; can assume } \\
\text { the shape of a bladder } \\
\text { or urethra }\end{array}$ & $\begin{array}{c}\text { Irregular or } \\
\text { spiculated (salt } \\
\text { dihydrate); rounded } \\
\text { (monohydrated } \\
\text { salt); sometimes } \\
\text { similar to metal } \\
\text { pebbles }\end{array}$ & $\begin{array}{c}\text { Smooth, rounded or } \\
\text { oval }\end{array}$ & $\begin{array}{l}\text { Smooth, rounded or } \\
\text { faceted }\end{array}$ & $\begin{array}{l}\text { Smooth to slightly } \\
\text { irregular, rounded to } \\
\text { oval }\end{array}$ & $\begin{array}{l}\text { Rounded center with } \\
\text { similar projections } \\
\text { and radii (jackstone) }\end{array}$ & -- \\
\hline
\end{tabular}


Research, Society and Development, v. 10, n. 12, e501101220876, 2021

(CC BY 4.0) | ISSN 2525-3409 | DOI: http://dx.doi.org/10.33448/rsd-v10i12.20876

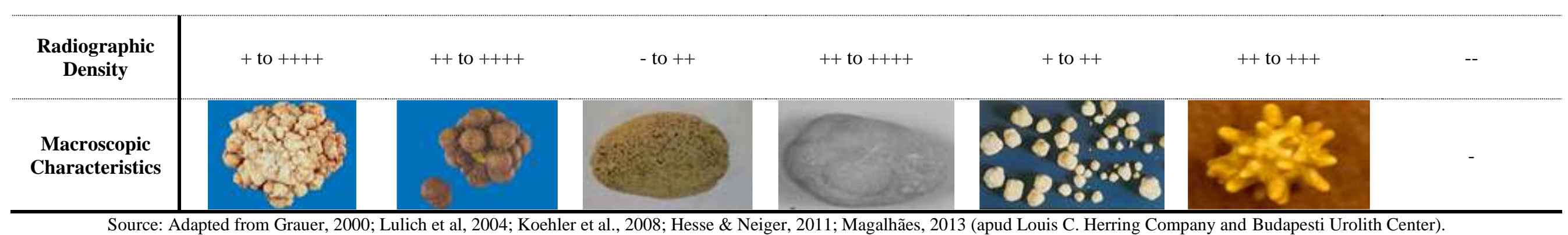

Source: Adapted from Grauer, 2000; Lulich et al, 2004; Koehler et al., 2008; Hesse \& Neiger, 2011; Magalhães, 2013 (apud Louis C. Herring Company and Budapesti Urolith Center). 
As for the anatomy and physiology, the urethra contains high pressure zones, in addition to longitudinal folds and thus trap bacteria and the natural peristalsis of the region, resulting in a unilateral flow of urine that together with mucosal barriers (containing glycosaminoglycans, antibodies, intrinsic antimicrobial properties), protect the animal from migration and colonization of bacteria and possible cell exfoliation. It is noteworthy that males have a greater predisposition to urethral obstruction than females, simply because the anatomical differentiation is related to a longer, narrower urethra with the presence of the penile bone. However, in females, there a greater predisposition to urinary infections, due to the urethra being close to the anus and to the floor when urinating. In addition, the four-feet position of dogs can interfere with complete emptying of the bladder, forming residual urine that can precipitate waste and form crystalline aggregates and a possible stone core. Regarding the urine composition, due to its acidity, high concentration of urea and high density, it has bactericidal power and, with the increase in urination, it is also essential in the expulsion of bacteria (Chew et al. 2011; Litster et al. 2011).

In all severe cases, patient stabilization with emergency hospitalization and possible surgery will be indicated (Lulich et al., 2008).

\section{Phytotherapy}

Phytotherapeutic substances are acquired from plant raw materials or even active compounds and thus act in the recovery of diseases or in the attenuation of their clinical symptoms, and their efficacy and safety are validated by clinical trials, duly supervised by ANVISA (Agency National Health Surveillance) and through published scientific documentation (Teixeira \& Santos, 2011). These natural products can be as efficient as those produced by chemical synthesis, however the transformation of a plant into a drug must aim to preserve the chemical and pharmacological integrity of the plant, ensuring the constancy of its biological action and its safety of use, in addition to maximizing its therapeutic potential. To achieve these goals, the production of herbal medicines necessarily requires studies related to botanical, agronomic, phytochemical, pharmacological, toxicological, development of analytical and technological methodologies (Malajovich, 2012).

In addition, biotechnology in phytopharmaceuticals deals with commitments or future prospects for innovative biotechnological products and processes, leading to investment and research opportunities (Malajovich, 2012). For more advanced studies related to herbal medicine, it is recommended that medicines made from medicinal plants have safety and quality of raw material, in their use and in their effectiveness, also demonstrating the possible limitations of use in toxicity and adverse effects (Teixeira, 2012). Dosage is essential to share the beneficial and toxic power of plants and in addition to interactions with allopathic medications, especially in cases of chronic diseases. The use of plants for long periods is not advisable, as the body may respond less and less to the treatment (Souza et al., 2012).

There are several advantages in using phytotherapy, these include: the cost-benefit ratio, as they are easily accessible, and their result has an identifiable and less aggressive pharmacological effect. The presence of new substances with which the pathogens have had no contact also help avoid drug resistance. It is worth remembering that modern veterinary medicine production techniques are associated with all stages of product development (stability, efficacy, and safety), which guarantee an effective clinical result (Guedes et al., 2016).

Several medicinal plants have been studied and highlighted with diuretic, antimicrobial, anti-inflammatory, antispasmodic, antioxidant, inhibitors on crystallization, nucleation and aggregation of crystals, which makes them effective in the treatment and prevention of urolithiasis (Nirumandi et al., 2018; Raditic, 2015). The effect of Phytotherapeutic drugs on the urinary $\mathrm{pH}$ is extremely valuable, as $\mathrm{pH}$ is one of the factors most related to the formation of calculi (Cruces et al., 2013).

As phytotherapeutic drugs contain several substances in their composition, their mechanism of action is still difficult to describe, but an increase in the glomerular filtration rate can be observed, and with this often-marked diuretic effect, they are indicated in bacterial infections and inflammatory conditions in kidney disease, being an auxiliary in the treatment and 
prophylaxis of urolithiasis. This effect of increasing urinary volume leads to the excretion of stones and mineral metabolites that influence the formation and growth of deposits. Plants with urinary antiseptic power are indicated for the prophylaxis of urolithiasis after the occurrence of UTI but can be used as an aid in recurrent and chronic inflammation of the urinary tract (Rodrigues, 2014; Silva, 2012).

Medicinal plants can also affect the mechanism of pathogenesis of microorganisms, aiding in the healing of mucous membranes in the urinary tract, which are most often injured. (Santos, 2016).

A schematic presentation of the medicinal plants most used in animal treatments with urolithiasis is given in Table 2 . Individual descriptions, safe dosages and effectivity in empirical doses or described in the literature can also be observed. A prescription will depend on the clinical situation of each animal and can be used alone or in synergistic combinations.

Apium graveolens L. belongs to the Apiaceae family and is a biennial herbaceous plant that grows to a height of about 60 to $90 \mathrm{~cm}$, being native to Eurasia and is cultivated mainly in coastal regions in soils with a high salt content or in wet and swampy locations. The most used part of the plant for therapeutic purposes is the seeds, which are found in the flowers. These seeds are very small, dark brown in color and have a strong, pleasant smell. The seeds of A. graveolens have antimicrobial activity due to the essential oils present, as well as a diuretic effect, which is mainly conferred by flavonoids. The roots of $A$. graveolens, although employed much less frequently than the seeds, can be used due to their more pronounced diuretic activity, which is beneficial in cases of UTIs (Fraqueza, 2018).

In vitro studies pointed to the potential diuretic and antimicrobial activity of the seeds of this plant. However, in vivo studies that demonstrate the positive effects of this plant on UTIs (weakness) are still very scarce. There is also an antiadhesive potential, which validates the traditional use of A. graveolens in UTIs, since, after 4 to 7 days of treatment, a significant reduction in the bacterial load on the surface of the bladder is observed. A study on the action of A. graveolens root as a diuretic using rats concluded that the ethanolic and aqueous extract of the root of this plant had significant diuretic activity compared to furosemide. The seeds and roots of A. graveolens are an option in cases of genitourinary inflammation, being used in traditional medicine for the treatment of urinary tract diseases with antimicrobial and diuretic activity (Fraqueza, 2018).

Arctostaphylos uva-ursi, belonging to the Ericaceae family (Teixeira, 2012), is a perennial and creeping shrub that grows in wetlands with undergrowth in North America, Europe and Asia. It has small, creeping, reddish-brown branches, pink or white, bell-shaped flowers that bloom in summer, followed by bright, red berries, which are edible but have a bitter taste (Fraqueza, 2018). The parts of this plant that are used are its dry leaves, fragmented or whole, being defined by the Portuguese Pharmacopoeia IX that must present a minimum content of hydroquinonic derivatives, expressed in anhydrous arbutin $\left(\mathrm{C}_{12} \mathrm{H}_{16} \mathrm{O}_{7}\right)$ to $7.0 \%$ (Rodrigues, 2014). 
Table 2. Main species of plants used in clinical practice with their specifications.

\begin{tabular}{|c|c|c|c|c|c|c|}
\hline SCIENTIFIC NAME & FAMILY & USE & FUNCTION & $\begin{array}{l}\text { POSOLOGY/ } \\
\text { DOSAG }\end{array}$ & $\begin{array}{c}\text { TOXICITY } \\
\text { (high doses } \backslash \\
\text { prolonged use) }\end{array}$ & REFERENCES \\
\hline Apium graveolens $L$. & Apiaceae & UTI & $\begin{array}{l}\text { D-limonene and selinene, flavonoids, } \\
\text { furanocoumarins, glycosides and triglycerides }\end{array}$ & $\begin{array}{c}\text { Plant infusion: } 3 \mathrm{~g} \text { of the whole } \\
\text { planta in } 150 \mathrm{~mL} \text { of water } \\
\text { Offer } 3 \mathrm{ml}, 3 \text { to } 4 \text { times a day for } 15 \\
\text { days }\end{array}$ & $\begin{array}{l}\text { Kidney } \\
\text { inflammation, } \\
\text { Gestation }\end{array}$ & Fraqueza, 2018 \\
\hline Arctostaphylos uva-ursi & Acariceae & UTI, Diuresis & $\begin{array}{l}\text { hydroquinonic heterosides, methyl arbutoside, } \\
\text { hydroquinone and methyl hydroquinone, } \\
\text { flavonoids, pentacyclic triterpenes, piceoside, } \\
\text { allantoin }\end{array}$ & $\begin{array}{c}10 \mathrm{mg} / \mathrm{kg} \text { of dry extracts twice a } \\
\text { day }\end{array}$ & Hepatotoxic & $\begin{array}{l}\text { Fraqueza, } 2018 \\
\text { Rodrigues, } 2014 \\
\text { Santos, } 2012 \\
\text { Teixeira, } 2012\end{array}$ \\
\hline Costos sp. & Zingiberaceae & UTI, Diuresis & $\begin{array}{l}\text { Oxalic acid, essential oil, tannins, mucilage, } \\
\text { saponins, sapogenins, pectins, systolesterol, } \\
\text { potassium acid oxalate, magnesium oxalate, iron } \\
\text { oxalate II, magnesium oxalate II, potassium } \\
\text { chloride, glucose, and chlorophyll }\end{array}$ & $\begin{array}{c}\text { Plant infusion: } 6 \mathrm{~g} \text { of the whole } \\
\text { planta in } 200 \mathrm{~mL} \text { of water } \\
\text { Offer } 3 \mathrm{ml}, 3 \text { to } 4 \text { times a day for } 15 \\
\text { days }\end{array}$ & $\begin{array}{l}\text { Gestation, } \\
\text { Lactation }\end{array}$ & $\begin{array}{c}\text { Duarte, Andrade \& Oliveira, } 2017 \\
\text { Bezerra et al., } 2014\end{array}$ \\
\hline $\begin{array}{l}\text { Echinodorus } \\
\text { macrophyllus }\end{array}$ & Alismataceae & Diuresis & $\begin{array}{l}\text { Flavonoid diterpenes derived from steroid o- } \\
\text { hydroxycinnamic acid, fatty acids, simple } \\
\text { arylpropanoids o-hydroxycinnamic acid and } \\
\text { trans-aconitic acid, essential oil }\end{array}$ & $\begin{array}{l}5 \mathrm{mg} / \mathrm{kg} \text { of dry extract twice a day } \\
\text { for } 30 \text { days }\end{array}$ & $\begin{array}{l}\text { Risk of } \\
\text { degenerative } \\
\text { diseases }\end{array}$ & $\begin{array}{l}\text { Leite et al., } 2007 \\
\text { Veiga, } 2012 \\
\text { Santos et al., } 2017\end{array}$ \\
\hline Equisetum arvense & Equisetaceae & UTI, Diuresis & $\begin{array}{l}\text { Mineral salts, aluminum, and other minerals such } \\
\text { as sulfur, phosphorus, sodium, zinc and } \\
\text { manganese, flavonoids, alkaloids, saponoside, } \\
\text { echisetonin (5\%), phytosterols, salicylic acid, } \\
\text { phenolic acids, saponins, tannins and essential oil }\end{array}$ & $\begin{array}{l}5 \mathrm{mg} \backslash \mathrm{kg} \text { of dry extract twice a day } \\
\text { for } 30 \text { days }\end{array}$ & $\begin{array}{l}\text { Heart or kidney } \\
\text { disease, } \\
\text { Gestation } \\
\text { Lactation } \\
\text { Puppies }\end{array}$ & $\begin{array}{l}\text { Fraqueza, } 2018 \\
\text { Santos, } 2016\end{array}$ \\
\hline Percia americana & Lauraceae & Diuresis & $\begin{array}{l}\text { Tannins, terpenes, malic and acetic acid, } \\
\text { dopamine, asparagine, methyl eugenol, methyl } \\
\text { chavicol and perseitol, carbohydrates, proteins, } \\
\text { essential oil, mineral salts, fats and pigment }\end{array}$ & $\begin{array}{l}\text { Plant infusion: } 0.5 \mathrm{~g} \text { of plant leaves } \\
\text { in } 150 \mathrm{~mL} \text { of water. } \\
\text { Offer } 3 \mathrm{ml}, 3-6 \text { times/day or of } 1-3 \\
\text { drops } / \mathrm{kg} / \text { day of } 10 \% \text { tincture } 2-3 \\
\text { times/day }\end{array}$ & $\begin{array}{l}\text { Gestation } \\
\text { Lactation }\end{array}$ & $\begin{array}{l}\text { Marques, } 2017 \\
\text { Martins, } 2017\end{array}$ \\
\hline Phyllanthus niuru & Phyllanthaceae & Urolithiasis & Alkaloids, flavonoids, lignans and triterpenes & $\begin{array}{l}\text { Infusion plant: } 10 \mathrm{mglkg} 3 \mathrm{~g} \text { of the } \\
\text { whole planta in } 150 \mathrm{~mL} \text { of water } \\
\text { Offer } 3-5 \mathrm{ml}, 3-4 \text { times a day }\end{array}$ & Abortive & $\begin{array}{l}\text { Queiroga et al., } 2014 \\
\text { Lee et al., } 2016 \\
\text { Marques, } 2013\end{array}$ \\
\hline
\end{tabular}


Research, Society and Development, v. 10, n. 12, e501101220876, 2021

(CC BY 4.0) | ISSN 2525-3409 | DOI: http://dx.doi.org/10.33448/rsd-v10i12.20876

\begin{tabular}{|c|c|c|c|c|c|c|}
\hline & & & & for $15-30$ days & & $\begin{array}{l}\text { Cruces et al., } 2013 \\
\text { Bezerra et al., } 2014\end{array}$ \\
\hline Vaccinum macrocarpon & Ericaceae & UTI & $\begin{array}{l}\text { flavonoids, flavonols, catechins, triterpenoids } \\
\text { organic acids carbohydrates, vitamin A, mineral } \\
\text { salts, tannins, pectins, macroelements } \\
\text { microelements Vitamin C }\end{array}$ & $\begin{array}{l}5 \mathrm{mg} \mid \mathrm{kg} \text { of dry extract twice a day } \\
\text { for } 30 \text { days }\end{array}$ & $\begin{array}{l}\text { Concurrent use with } \\
\text { warfarin }\end{array}$ & $\begin{array}{c}\text { Fraqueza, } 2018 \\
\text { Dagostin, } 2016 \\
\text { Olszewski, } 2017 \\
\text { Rodrigues, } 2014 \\
\text { Teixeira, } 2012 \\
\text { SANTOS, } 2016\end{array}$ \\
\hline Zea mays $L$. & Poaceae & UTI, Diuresis & $\begin{array}{l}\text { Potassium salts, flavonoids, tannins, salicylic } \\
\text { acid, amines, saponins and steroids }\end{array}$ & $\begin{array}{l}\text { Infusion } 2-3 \text { hairs from the spikes } \\
\text { in } 200 \mathrm{ml} \\
\text { Offer } 3-5 \mathrm{ml}, 6 \text { times a day for } 15 \\
\text { days }\end{array}$ & $\begin{array}{l}\text { Heart or kidney } \\
\quad \text { failures, } \\
\text { Gestation, Lactation }\end{array}$ & $\begin{array}{l}\text { Queiroga, } 2015 \\
\text { Fraqueza, } 2018 \\
\text { Campos, } 2019\end{array}$ \\
\hline
\end{tabular}

Source: Authors (2021). 
The active constituents of interest in Arctostaphylos uva-ursi are essentially the hydroquinonic heterosides, including arbutoside or arbutin (hydroquinone glucoside) and smaller amounts of methyl-arbutoside, hydroquinone and methylhydroquinone. There are also other compounds that intervene in its pharmacological action, such as hydrolyzable and condensed tannins, flavonoids, pentacyclic triterpenes, piceoside, allantoin (Rodrigues, 2014). The antimicrobial activity of arbutin depends on hydrolysis caused by bacterial $\beta$-glucosidases present in the intestinal flora. Hydroquinonic heterosides undergo hydrolysis by the intestinal flora (Teixeira, 2012). They are transported to the liver where they are metabolized through a process of conjugation with glucuronic or sulfuric acid, and subsequently excreted via the kidneys. These active metabolites undergo hydrolysis with the release of hydroquinone, which has antiseptic properties, in the urinary tissue, at alkaline pH (Fraqueza, 2018; Santos, 2016). The genera with the highest microbial activity are Enterobacter sp., Klebsiella sp. and Enterococcus sp., with the Escherichia coli species having a lower activity (Fraqueza, 2018).

Arbutin does not undergo hydrolysis in the acidic environment of the stomach, and thus arrives intact in the intestine where it is converted by $\beta$-glucosidases to hydroquinone. This compound is absorbed and then metabolized in the liver to sulfo-conjugated derivatives and hydroquinone glucoconjugates which are eliminated via the kidneys in the urine. In case of bacterial infection, the hydroquinone conjugates are hydrolyzed to hydroquinone by microbial $\beta$-glucosidases. Hydroquinone acts as an antimicrobial in the bladder (Fraqueza, 2018).

The use of this plant is mentioned in pharmacopoeias as a urinary antiseptic for moderate inflammatory conditions of the urinary tract, namely cystitis, urethritis, and dysuria (Santos, 2012; Teixeira, 2012). It has activity against the following urinary tract pathogens: E. coli, Proteus mirabilis, Pseudomonas aeruginosa, Staphylococcus aureus, and others. The pharmacological action, essentially the presence of hydroquinonic heterosides which, despite being poorly absorbed in the gastrointestinal tract, undergo hydrolysis by microbial $\beta$-glucosidases from the intestinal flora, giving rise to the formation of glucuroconjugate and sulfo-conjugated derivatives. These derivatives, after being absorbed, are then eliminated in the urine which, in case of infection, undergo hydrolysis with the consequent release of hydroquinone. It is important to point out that this hydrolysis is favored by a urine with an alkaline $\mathrm{pH}(\sim 8)$, consequently having a greater antiseptic effect, and this alkaline $\mathrm{pH}$ can be achieved with dietary measures and ingestion of sodium bicarbonate or potassium citrate solution (Rodrigues, 2014).

Tannins and flavonoids, also present in bearberry leaves, have an anti-inflammatory and diuretic action (Teixeira, 2012). The anti-inflammatory and diuretic properties of this plant complement its antibacterial action in the prevention and treatment of UTIs (Santos, 2016). The anti-inflammatory activity was detected through the rat paw edema test, and the diuretic action, but with low elimination of sodium and potassium. In vitro studies show that the 50\% methanol extract of the leaves of this plant, as well as arbutin itself, have an inhibitory activity on the tyrosinase enzyme. Consequently, there may be interferences in the synthesis of melanin, as this enzyme is involved in the production processes of this compound (Rodrigues, 2014).

The plant Costus spiralis (Jacq.) Roscoe, belongs to the Zingiberaceae family, is a native species of Mexico, Costa Rica, Colombia and Brazil and has been used in traditional medicine for a long time, mainly in the Amazon region. It preferentially occurs in humid places, but it can also be found in savannas and granitic outcrops (Duarte, Andrade \& Oliveira, 2017). It is an herbaceous, rhizomatous plant with a perennial cycle that can measure from $80 \mathrm{~cm}$ to $1.5 \mathrm{~m}$. Its stems are hard, cylindrical. Young shoots are thicker than adults. Its leaf is dark green, with a hairy and reddish sheath on the margins. The flowers are yellow and grouped in terminal spike-type inflorescences, surrounded by reddish scaly bracts. The fruit is of the 
capsule type, with many seeds rounded at the apex. The parts with medicinal uses are the leaves, stem, and rhizome (Bezerra et al., 2014).

Ethnopharmacological information register the use of roots and rhizomes as a diuretic and tonic, causing perspiration (diaphoretic), and the juice, from fresh stems and leaves diluted in water, is indicated against nephritis, bladder problems and diabetes. Externally, the decoction is used to relieve vaginal irritations, leucorrhea and to treat ulcers. C. spiralis has been used as an ornamental plant and used in folk medicine for the treatment of hypertension and renal dysfunction and as a diuretic agent (Duarte, Andrade \& Oliveira, 2017).

Oxalic acid, essential oil, tannins, mucilage, saponins, sapogenins, pectins, systolesterol, potassium acid oxalate, magnesium oxalate, iron oxalate II, magnesium oxalate II, potassium chloride, glucose and chlorophyll are the chemical compounds present in plant Costus sp. (Bezerra et al., 2014). In the methanol extract, the following constituents were found: flavonoids, steroids, and alkaloids (Duarte, Andrade \& Oliveira, 2017).

In one study, calcium oxalate crystals were implanted in rats to induce the formation of kidney stones, and after administration of the aqueous extract of C. spiralis, stone reduction was observed, thus suggesting that tea from this plant has anti-urolithic activity. The effect of the anti-urolithic activity, however, is not related to increased diuresis or a change in the affinity of the muscarinic receptor of the smooth muscle of the bladder, but rather to cholinergic bonds (Duarte, Andrade \& Oliveira, 2017).

Echinodorus macrophyllus of the Alismataceae family, occurs in Minas Gerais and São Paulo - Brazil (Leite et al., 2007) and can be found mainly in flooded areas. It is an acaulescent plant, with a short, erect, and elongated non-chlorophyll stem (rhizomes), with erect or elongated terminal shoots, which can be creeping (stems) and can reach up to $100 \mathrm{~cm}$ in height. Its leaves are petiolate, oval, with a codiform base and sharp or peaked at the apex, its color is dark green, ranging from 20 to $40 \mathrm{~cm}$ in length and width between 15 and $35 \mathrm{~cm}$ in the region near the base. Its petiole is long and leathery, measuring up to $70 \mathrm{~cm}$ in length. The flowers are white, with a yellowish "core", hermaphrodite and arranged in elongated branches (Veiga, 2012).

The leaves of E. macrophyllus leaves are popularly used to treat various diseases such as rheumatism and syphilis and are also used as a diuretic and to reduce uric acid. The in vitro and in vivo toxicity of the aqueous extract of E. macrophyllum leaves, in experiments carried out with rats, demonstrates the absence of genotoxic effect of this extract (Leite et al., 2007). However, the uncontrolled and long-term use of this extract may imply some risk of developing degenerative diseases (Santos et al., 2017).

In the chemical composition of E. macrophyllus, polyphenols, terpenes, tannins, and flavonoids were found as main secondary metabolites. Terpenes or terpenoids form the most numerous groups of vegetable secondary metabolites, with approximately 40.000 (forty thousand) different molecules. Phenolic compounds are part of a class of compounds that includes a variety of simple and complex structures, they have at least one aromatic ring, where at least one hydrogen is replaced by a hydroxyl group (Veiga, 2012).

The leaves of E. grandiflorus have in their composition diterpenes (clerodane and cembrane type), flavonoids (Cheterosides of swertisin type flavones, isoorientin-7,3'-dimethylether, isoorientin, swertiajaponin and isovitexin), derivatives of acid o-hydroxycinnamic (chicoric and caftaric acids), steroids, fatty acids, simple arylpropanoids (caffeic, ferulic and isoferulic acid), o-hydroxycinnamic acid and trans-aconitic acid. The major component of E. grandiflorus essential oil is phytol, in addition to the sesquiterpenes (E)-caryophyllene, $\alpha$-humulene and (E)-nerolidol (Santos et al., 2017). 
Equisetum arvense L. (horsetail) is a perennial plant that grows in clayey, wet, or sandy soil, and can be found in North America, Europe and Asia (Fraqueza, 2018; Santos, 2016). This plant has an unusual morphology and has two stages of growth (Santos, 2016). The first reddish-colored stem grows from the fertile trunk that reaches between $10-18 \mathrm{~cm}$ and has at its end the spike that produces the spores. These stalks, after completing their function, wither and are replaced by the second stalks. The second stem, also known as the sterile stem, is the part of the plant used for therapeutic purposes (Fraqueza, 2018). This form of the plant does not have a long life and gives way to a stalk with a green hue, consisting of spirals of small branches and is $\sim 50 \mathrm{~cm}$ tall (Santos, 2016).

The chemical composition of sterile parts (sterile stems) has the mineral salts magnesium, calcium, potassium (2 to $3 \%$ ), aluminum, and other minerals such as sulfur, phosphorus, sodium, zinc and manganese, flavonoids (mainly quercetin glycosides, of kaempferol and hyperoside), alkaloids, saponoside, echisetonin (5\%), phytosterols, salicylic acid, phenolic acids, saponins, tannins and essential oils (Fraqueza, 2018). Phenolic compounds have simple and complex structures with at least one aromatic ring, where hydrogen is replaced by the hydroxyl group (Temoteo, 2017). The high concentration of flavonoids, phenolic compounds and minerals give this plant a diuretic action (Santos, 2016). It is widely used in the treatment of urinary infections, justifying its use due to its diuretic action, the presence of potassium salts and flavonoid glycosides; and for the antimicrobial activity of its essential oil (Rodrigues, 2014).

The diuretic effect has already been tested in several in vivo studies, presenting a regulatory and astringent action on the genitourinary tract, acting as a diuretic, and helping to treat moderate infections of the lower urinary tract. In a study carried out with an E. arvense preparation and tested in dogs, a 15-20\% superior diuretic effect compared to water was observed (Santos, 2016). There are also studies that report that horsetail has antioxidant and astringent activity (Fraqueza, 2018). Studies have demonstrated the in vitro antimicrobial activity of the essential oil present in the constitution of E. arvense L. on the bacteria E. coli, Klebsiella pneumoniae, Pseudomonas aeruginosa, Salmonella enteritidis, Staphylococcus aureus, thus contributing to the medicinal properties of this plant (Santos, 2016). In the treatment of urinary infections, it is currently only recommended as a diuretic to promote the renal elimination function, and in irrigation therapy in bacterial and inflammatory diseases of the lower urinary tract, such as in cystitis and other urinary inflammations (Fraqueza, 2018).

E. arvense has properties that strengthen both the bladder and kidney tissue. These tonifying effects facilitate the reduction of inflammation in diseases such as kidney stones, bladder and kidney infections, bladder weakness, kidney weakness and urinary incontinence. It is used in traditional folk medicine to treat kidney stones and urinary problems, in addition to increasing the amount of urine to wash the urinary tract (Santos, 2016).

Belonging to the Lauraceae family, Persea americana is a tree with a rounded and dense crown, 12-20 m high, native to Central America, its simple leaves, cartaceous, 9-18 cm long, with a short trunk of $40-70 \mathrm{~cm}$ of $9 \mathrm{~cm}$ in diameter, coated with brown and rough bark. Its main chemical compounds are tannins, terpenes, malic and acetic acid, dopamine, asparagine, methyl eugenol, methyl chavicol and perseitol, in addition to carbohydrates, proteins, essential oils, mineral salts, fats and pigment A preclinical study carried out with the aqueous extract of $P$. americana leaves indicated that the extract has analgesic and anti-inflammatory effects. In in vitro crystallization tests in human urine, with calcium oxalate crystals, the extract of $P$. americana proved to be efficient in inhibiting the formation of crystals and increasing urinary volume (Martins, 2017).

Phyllanthus niuri L. belongs to the genus Phyllanthus sp., family Euphorbiaceae, which comprises more than 600 species, widely distributed in tropical and subtropical countries. It is a native plant from America, specifically from southern Brazil, occurring in almost all regions. It grows spontaneously as a weed and invasive plant (Queiroga, 2015). It is a hebaceous, annual plant, reaching up to $0.5 \mathrm{~m}$ in height, branched, with globose branches (devoid of hair), leaf with limb (wide 
and flat part of the leaves), alternating, found very commonly in the rainy period on the sidewalks, gardens and vacant lots and has small, yellow, or greenish flowers arranged in the lower part of the branches (Bezerra et al., 2014).

More than 50 compounds have been identified in P. niruri, including alkaloids, flavonoids, lignans and triterpenes. The alkaloids present in the Phyllanthus genus have antispasmodic activity, favoring smooth muscle relaxation and elimination of urinary calculus. Triterpenes inhibit $\mathrm{CaOx}$-induced cytotoxicity, in addition to reducing renal crystal deposition. Pentacyclic triterpenes have been identified as hepatoprotective, hypolipidemic, antilithogenic, anticancer and anti-inflammatory. Lupeol, one of the triterpenes present in this plant extract, reduced the formation of calculi by diluting promoters and protecting tissues (Cruces et al., 2013).

The methanol extract of the plant moderately inhibited xanthine oxidase. The inhibition of $P$. niruri on CaOx crystallization does not decrease the number of crystals but induced a reduction in their size and aggregation in urine and this effect may have occurred due to interference in the early stages of stone formation, thus representing a complementary methodfor treatment and prevention of urolithiasis (Cruces et al., 2013).

The in vitro effect of a $P$. niruri extract on calcium oxalate $(\mathrm{CaOx})$ crystallization was studied by Lee et al. (2016) and it was observed that $P$. niruri restricted both the growth and aggregation of $\mathrm{CaOx}$ crystals, thus demonstrating its potential to interrupt early-stage stone formation. Additionally, $P$. niruri modified the shape of the stones in rats to possibly form a smoother and more fragile deposit. This could facilitate the removal and/or dissolution of stones. A further clinical study also demonstrated that $P$. niruri can reduce urinary calcium in hypercalciuric patients and that post-shock wave lithotripsy patients receiving $P$. niruri therapy had higher rates of stone clearance than the control group (Lee et al., 2016).

The methanol extract of $P$. niruri decreases uric acid levels in the plasma of hyperuricemic rats, but it does not act in normal rats. This study included fractionation of methanol extract, and the less polar fraction exhibited the greatest reduction in plasma uric acid. This effect was attributed to the lignans philantine, hypophylanthine and filtetralin, which reverted plasma uric acid levels in hyperuricemic animals to normal levels in a dose-dependent manner and in a manner comparable to drugs clinically used in the treatment of such conditions (Marques, 2013).

It has anti-inflammatory, antifungal, antiviral, antibacterial, antioxidant, hepatoprotective, hypoglycemic, hypotensive, analgesic and antilithogenic activities. P. niruri has been evaluated for the prevention and dissolution of calculi. Due to its uricosuric property, it is of great interest in the control of hyperuricemia. $P$. niruri also displayed hypoglycemic and antibacterial action against Staphyococcus and anticancer (Bezerra et al., 2014).

The beneficial effects of the P. niruri for the treatment and prevention of urolithiasis can be summarized by the following mechanisms of action (Marques, 2013):

1) Inhibition of calcium oxalate endocytosis by renal tubular cells, interfering with the formation of kidney stones.

2) Inhibition of the growth and aggregation of calcium oxalate crystals, facilitating their elimination. Some hypotheses about the ability of $P$. niruri to prevent the growth of the crystalline part of the stones (without interfering with the adsorption of GAGs - protein matrix) are: GAG negative charge neutralization reducing the negative pole to progressive cation deposition; active components could chelate and/or compete with calcium for binding sites on the crystal surface; effect on other proteins, such as nephrocalcin and osteopoietin, with the potential to modulate crystallization, aggregation and stone growth.

3) Change in the morphology and texture of kidney stones, facilitating their elimination.

4) Analgesic activity: potent and long-lasting antinoceptive activity demonstrated in several pain models. 
5) Antispasmodic activity due to inhibition of smooth muscle contraction of the ureter, facilitating the elimination of kidney stones.

P. niruri also increases glomerular filtration and urinary excretion of uric acid, which confirms its efficiency in expelling kidney stones, antibacterial, hypoglycemic, anticancer, muscle relaxant (appears to be specific for the ureters), clearing and anti-blocking activities. The hepatitis B virus and liver problems (Bezerra et al., 2014). It exhibits potent analgesic properties against neurogenic and inflammatory pain, and the mechanisms responsible for the antinociceptive action are not related to central depressant action, inhibition of prostaglandin synthesis, release of endogenous opioids or glucocorticoids, interaction with serotonergic or alpha-adrenergic receptors, or interaction with via L-arginine nitric oxide (Marques, 2013).

The absence of acute or chronic toxicity, in addition to suggesting normalization of calcium levels and elimination of uroliths in animals, in addition to not detecting harmful effects of $P$. niruri on the renal, cardiac, and neurological systems in humans. There is a hemorrhagic tendency in rats with urolithiasis, induced by ethylene glycol, although inhibition of the deposition of $\mathrm{CaOx}$ salts has been demonstrated (Cruces et al., 2013). P. niruri is abortive when used in excessive doses (Marques, 2013).

Vaccinium macrocarpon, belongs to the Ericaceae family and is commonly referred to as cranberry. It originates from North America and is characterized by being a low bush (5 to 20 centimeters tall) and long ( 2 meters long). It has small green leaves, dark pink flowers and the fruit is a berry that is born white, turning red as it matures (Santos, 2016). The part of the plant used for therapeutic purposes are the fruits (berries), which are small, 1 to 2 centimeters in diameter, with an acid taste and an intense red color (Fraqueza, 2018).

The main constituents of the V. macrocarpon plant are flavonoids (especially anthocyanins), flavonols, catechins, triterpenoids (ursolic acid is the most commonly found, concentrated in the skin of the fruit), organic acids (butyric, malic, glucuronic, citric and quinine), carbohydrates (mainly fructose), vitamin A, mineral salts and tannins (Dagostin, 2016), in addition to pectins, macroelements (potassium, phosphorus, nitrogen and magnesium) and microelements (iron, manganese, copper and zinc) (Fraqueza, 2018). The amount of vitamin C present in the fruit is high, around $200 \mathrm{mg} / \mathrm{kg}$ of fresh berries. Its flavor comes from the presence of chemical constituents known as iridoid glycosides (Dagostin, 2016).

Amongst the compounds found in V. macrocarpon proanthocyanidins (PAC) and condensed tannins, have the greatest therapeutic relevance for the prevention and treatment of UTIs due to their antimicrobial activity (Santos, 2016). PACs are characterized as epicatechin tetramers and pentamers and are part of the phenylpropanol metabolism. They have a type A interflavonoid bond; therefore, they are called type A proanthocyanidins and represent about $94.5 \%$ of the PACs present in the fruit. PACs inhibit the adhesion of bacteria, especially E. coli, to the epithelial wall of the urinary tract, consequently preventing them from growing and reproducing (Dagostin, 2016).

$V$. macrocarpon is the species that has been most used in the treatment of UTIs, both curative and preventive. It is used in the form of common preparations such as whole fresh berries, gelatinized products, juices and even capsules, and in this case, the fruits are also the part of the plant used in this therapy (Rodrigues, 2014). Cranberry has several therapeutic actions such as anticancer, cardiovascular system protector, antifungal, in addition to having an antibacterial action, preventing, for example, diseases such as UTI. Anthocyanins and proanthocyanidins are tannins that have a natural defense function against microbial cells, they are sources of excellent high-quality antioxidants. Anthocyanins can act on bacterial cells by breaking the cytoplasmic membrane and Type A PAC, the only ones found in cranberry, can help prevent certain harmful bacteria from proliferating in the body by interfering with bacterial adhesion in different tissues (Olszewski, 2017). With the growing 
resistance to antibiotics, the interest in products such as cranberry, can be considered an alternative for association with antibiotics in the control of UTIs.

The mechanism of action of $V$. macrocarpon was initially attributed to the transformation of benzoic acid into hippuric acid, which would act by decreasing urine $\mathrm{pH}$ and, consequently, leading to bacteriostasis. In addition, another form of bacteriostasis would be through acidification of the urine by ingesting large amounts of vitamin $\mathrm{C}$ present in the fruit (Dagostin, 2016). However, the currently most accepted model is based on the ability to inhibit the adhesion of bacteria to the urinary tract mucosa, preventing the adhesion of type 1 and p fimbriae of bacteria, especially E. coli, to the urinary tract epithelium. Thus, if there is no adhesion step, bacteria cannot infect the mucosal surface. It is important to mention that, in vitro, this adhesion is mediated by two components of these plants: fructose, which acts inhibiting the adhesion of type 1 fimbriae, and proanthocyanidins, which inhibit the adhesion of type p fimbriae (Rodrigues, 2014).

Some bacteria, including E. coli, have on their cell surface several flagella and many fimbriae, which are necessary for colonization during the infectious process. Fimbriae may contain lectins that are proteins necessary for bacterial adhesion to the host cell. Uropathogenic E. coli strains have P-type fimbriae with adhesins at their tip, whose function is to adhere to an epithelial cell receptor bladder walls, making this step a key factor in the development of infection. Type A anti-adhesive PAC molecules present in cranberry juice are the agents responsible for causing the fimbriae to change its configuration and subsequently shrink. This blockage of its adhesive action occurs by inhibiting the cellular expression of adhesive molecules or by inhibiting their development (Olszewski, 2017; Teixeira, 2012).

PACs are also considered anti-inflammatory, anti-allergic, vasodilating, cardioprotective, immunostimulant, antiviral and inhibiting cellular oxidative stress and induced chemical carcinogenesis, inhibiting enzymes involved in the proliferation of cancer cells in humans, interfering with the expression and number of genes necessary for cells to grow and be able to activate the apoptotic specificity of proteins that initiate cell death. The antioxidants present in cranberry also can bind to low density lipoprotein (LDL) and protect them from oxidation, in addition to increasing their antioxidant capacity in plasma and increasing HDL (High density lipoprotein) levels (Olszewski, 2017). Ingesting high amounts of these juices can help to eliminate bacteria from the urinary tract by increasing diuresis, while juices with higher amounts of PAC, as well as other formulations such as capsules or tablets, act by the non-stick action of bacteria that helps to prevent ITUs (Fraqueza, 2018).

Zea mays L. belongs to the Graminaceae or Poaceae family and is commonly known as corn. It belongs to the group of angiosperms, that is, it produces seeds in the fruit, also receiving the name of corn and turkey wheat (Queiroga, 2015). It is an herbaceous plant native to the Andes and Central America and widely cultivated around the world. The part of the plant used for therapeutic purposes are the stylets and stigmas, commonly known as corn beards (Fraqueza, 2018). The plants have an average of 1.30 to $2.50 \mathrm{~m}$ in height, erect stem, cylindrical, fibrous, separated into potions by buds and, generally, covered by a part of the leaf, called a sheath. The leaves are medium to large, dark to light green in color, flexible and have a white, smooth and clearly visible midrib. The plant produces a male flower (arrow or tassel) in its highest part, where it produces the pollen grains and the female flower (ear) at the middle of the leaves and forms an inflorescence. From each female flower comes an elongated stylet, the set, at the end of the ear, forms a kind of beard known as corn stigmas. Each strand (hair or stigma) that comes out of the ear is responsible for the production of a grain, after it is fertilized (Queiroga, 2015).

The stylets and stigmas have a high content of potassium salts, flavonoids, tannins, salicylic acid, amines, saponins and steroids in their chemical composition. Corn stalks, due to potassium salts and flavonoids present in their chemical composition, have diuretic activity that helps to promote proper kidney function. Thus, corn stalks are widely have been used in traditional medicine since the Incas, mainly in the form of infusion, as a diuretic in uncomplicated urinary tract infections. 
Preclinical studies carried out in animals have demonstrated the beneficial effect of $Z$. mays as a diuretic, however there are some studies that have reached contradictory results, raising questions about whether the duration of the intervention and/or the dose administered were sufficient to induce the desired response. Z. mays is contraindicated for animals with heart or kidney failure, pregnancy, and lactation as a uterine stimulation due to sterols was observed. It can cause allergic reactions, and prolonged or excessive use is not recommended due to the risk of causing vomiting, cramps, and diarrhea (Fraqueza, 2018).

Studies carried out have shown that the diuretic effect must be caused by the decrease in tubular reabsorption of sodium, which, consequently, leads to its excretion accompanied by a greater volume of urine. This is in agreement with the hypotension found in animals treated with this herbal medicine, because the conversion of angiotensin I into II does not occur, causing vasodilation (Campos, 2020).

\section{Final Considerations}

From this systematic review it can be concluded that some medicinal plants can contribute to the treatment of urolithiasis, due to different factors, reducing the rates of recurrence and surgical emergency, which collaborates with the veterinary community who work in the clinic to amplify the use of technique as the efficient treatment of this pathology, in addition to leaving the guardians satisfied with the well-being and quality of life of their animals. There is still a need for further research and dissemination of information regarding the use of medicinal plants in animals, but despite the biotechnology of these products in the veterinary area being bureaucratic and similar to their use in humans, it was possible to see the various possibilities of the role of such plants in the treatment of urolithiasis in dogs with a promising basis for the safe and efficient use in addition to the possible creation of new products in the pet market.

In the furture, the authors will be uptade the presente article to reflect the advances in the field.

\section{Acknowledgments}

The authors would like to thank CAPES, CNPq and FAPEMIG.

\section{References}

Berent, A. C. (2016). Advances in urinary tract endoscopy. The Veterinary clinics of North America. Small animal practice. 46, $113-135$.

Bezerra, W. K. T.; das Silva, M. D. G.; Bezerra, A. M. F.; Santo Bezerra, K. K.; Vieira, A. L.; Pereira, D. S.; Borba Borges, M. G. (2014). O uso de fitoterapia com ação anti-inflamatória que atuam no sistema gênito-urinário. Informativo Técnico do Semiárido, 8, 24-36.

Campos, B. I. D. (2020). Relatórios de Estágio realizado na Farmácia Lusa de Paredes e no Centro Hospitalar Universitário do Porto, Porto.

Chew, D.; Dibartola, S.; Schenck, P. (2011). Canine and feline nephrology and urology. 2nd ed. Saint Louis (MO): Elsevier Saunders.

Cruces, I.; Patelli, T.; Tashima, C.; Mello-Peixoto, E. (2013). Plantas medicinais no controle de urolitíase. Revista Brasileira de Plantas Medicinais, 15, 780788.

Dagostin, S. F. F. (2016). Utilização de Vaccinium macrocarpon (Cranberry) para prevenção de infecção urinária recorrente: revisão da literatura e divulgação a profissionais de saúde. Dissertação (Pós-graduação em Farmacologia) - Universidade do Extremo Sul Catarinense, Criciúma.

Duarte, R. C.; Andrade, L. A.; Oliveira, T. (2017). Revisão da planta Costus spiralis (JACQ.) Rroscoe: pluralidade em propriedades medicinais. Revista Fitos, $11,119-249$.

Fraqueza, A. C. M. (2018). A Fitoterapia na profilaxia e terapêutica de infeções do trato urinário não complicadas: o caso particular da cistite. Dissertação (Mestrado para Ciências Farmacêuticas Faculdade de Ciências e Tecnologias) - Universidade do Algarve, Faro.

Grauer, G. F. (2000). Urolitisis Canina. In: Nelson, R. W.; Couto, C.G. Medicina Interna de Animales Pequenos. Buenos Aires: Mosby, 687-698.

Grauer, G. F. Canine urinary tract infections. NAVC Clinician's Brief, p. 19-21, Kansas, 2012. 
Research, Society and Development, v. 10, n. 12, e501101220876, 2021 (CC BY 4.0) | ISSN 2525-3409 | DOI: http://dx.doi.org/10.33448/rsd-v10i12.20876

Guedes, R. A.; Marques, L. T.; Novaes, M. T.; Rodrigues, W. D.; Severi, J. A. (2016). Fitoterapia na medicina veterinária. Tópicos em Ciência Animal V, 1, $137-147$.

Hesse, A.; Neiger, R. (2011). A colour handbook of urinary stones in small animal medicine. Manson, 56-65.

Jericó, M. M.; Andrade Neto, J. P.; Kogika, M. M. Tratado de Medicina Interna de Cães e Gatos. Rio de Janeiro: RJ, 2015. 2v. 2464p.

Koehler, L. A.; Osborne, C. A.; Buettner, M. T.; Lulich, J. P.; Behnke, R. (2008). Canine urolithiasis: Frequently asked questions and their answers. Veterinary Clinics of North America: Small Animal Practice. 39, 161-181.

Lee, N. Y.; Khoo, W. K.; Adnan, M. A.; Mahalingam, T. P.; Fernandez, A. R.; Jeevaratnam, K. (2016). The pharmacological potential of Phyllanthus niruri. Journal of Pharmacy and Pharmacology, 68, 953-969.

Leite, J. P. V.; Pimenta, D. S.; Gomes, R. S.; Dantas-Barros, A. M. (2007). Contribuição ao estudo farmacobotânico da Echinodorus macrophyllus (Kunth) Micheli (chapéu-de-couro) Alismataceae. Revista Brasileira de Farmacognosia, 17, 242-248.

Litster, A. L.; Thompson, M. F.; Moss, S. M.; Trott, D. J. (2011). Feline bacterial urinary tract infections: an update on an evolving clinical problem. Veterinary Journal, 187, 18-22.

Lulich J. P., Osborne, C. A., Bartges, J.W.; Lekcharoensuk C. (2004). Distúrbios do trato urinário inferior dos caninos. In. ETTINGER, Stephen, J.; Feldman, E. C. Tratado de medicina interna veterinária - Doença do cão e do gato. 5.ed. Rio de Janeiro: Guanabara Koogan, $1847-1874$.

Lulich, J. P.; Adams, L. G.; Grant, D.; Albasan, H.; Osborne, C. A. (2008). Changing paradigms in the treatment of urolithiasis by lithotripsy. The Veterinary Clinics of North America. Small Animal practice. 39, 143-160.

Magalhães, F. D. A. (2013). Urolitíase em cães. Monografia (Facudade de Farmácia) - Universidade Federal do Rio Grande do Sul, Porto Alegre.

Malajovich, M. A. Biotecnologia 2011. Rio de Janeiro: Edições da Biblioteca Max Feffer do Instituto de Tecnologia ORT, 2012. p. $39-50$.

Marques, L. C. (2013). Phyllanthus niruri (quebra-pedra) no tratamento de urolitíase: Proposta de documentação para registro simplificado como fitoterápico. Revista Fitos, 5, 20-33.

Martins, A. A. M. (2017). Avaliação do potencial antilitiasico do extrato etanólico das folhas da Persea americana Mill. em modelo experimental. Dissertação (Programa de Pós-graduação em Ciências da Saúde) - Universidade federal da Grande Dourados, Dourados.

Nirumand, M. C.; Hajialyani, M.; Rahimi, R.; Farzaei, M. H.; Zingue, S.; Nabavi, S. M.; Bishayee, A. (2018). Dietary plants for the prevention and management of kidney stones: preclinical and clinical evidence and molecular mechanisms. International Journal of Molecular Sciences, 19 , 765-789.

Olszewski, V. R. (2017). Cranberries (Vaccinium macrocarpon Aiton) a nutrição de cães: influência na digestibilidade, palatabilidade e no curso de infecções do trato urinário. Dissertação (Programa de Pós-Graduação em Zootecnia - Universidade Federal do Paraná, Curitiba.

Pereira, A. S.; Shitsuka, D. M.; Parreira, F.J.; Shitsuka, R. (2018). Metodologia da pesquisa cientifica. Diposible in: https://repositorio.ufsm.br/bitstream/handle/1/15824/Lic_Computacao_Metodologia-Pesquisa-Cientifica.pdf?sequence=1. Acessed in: 27 set 2021.

Queiroga, G. M. T. (2015). Plantas medicinais e fitoterápicos como alternativa terapêutica às infecções urinárias: um diagnóstico dessa realidade na saúde pública de Mossoró. Dissertação (Programa de pós-graduação em ambiente tecnologia e sociedade) - Universidade Federal do Semi árido, Mossoró.

Raditic, D. M. (2015). Complementary and integrative therapies for lower urinary tract diseases. Veterinary Clinics: Small Animal Practice, 45, 857-878.

Rodrigues, A. R. V. (2014). Fitoterapia nas infeções urinárias. Dissertação (Mestrado Integrado em Ciências Farmacêuticas) - Universidade de Coimbra, Côimbra.

Rodrigues, M. C. T. (2021). Estudo retrospetivo da litíase urinária em cães e gatos. Tese (Doutorado Faculdade de Medicina Veterinária) - Universidade de Lisboa, Lisboa.

Santos, M. S. S. D. A (2016). Fitoterapia na Prevenção e Tratamento de Infeções do Trato Urinário. Dissertação (Mestrado Integrado em Ciências Farmacêuticas) - Universidade da Beira Interior, Covilhã.

Santos, R. R.; Fonseca, F. S. A. da; Fonseca, R. S.; Martins, E. R. (2017). Fenologia e quimiodiversidade do 'Chapéu-de-couro' (Echinodorus grandiflorus e Echinodorus macrophyllus). Caderno de Ciências Agrárias, 9, 115-118.

Silva, C. S. E. D. S. (2012). Plantas utilizadas como chás com propriedades anti-inflamatórias e antioxidantes. Dissertação (Mestrado em Ciências Farmacêuticas) - Universidade Lusófona de Humanidades e Tecnologias Faculdade de Ciências da Saúde, Lisboa.

Singh, S. K.; Agarwal, M. M.; Sharma, S. (2011). Medical therapy for calculus disease. British Journal of Urology, 107, $356-368$.

Souza, A. D. Z.; Heck, R. M.; Ceolin, T.; Borges, A. M.; Ceolin, S.; Lopes, A. C. P. (2012). O cuidado com as plantas medicinais relacionadas às infecções do trato uninário: um desafio à enfermagem. Revista de Pesquisa: Cuidado é fundamental online, 4, 2367-2376.

Souza, M. T. de; Silva, M. D. da; Carvalho, R. de. Revisão integrativa: o que é e como fazer. Einstein (São Paulo), v. 8, n. 1, p. 102-106, 2010.

Sturgess, K. (2009). Dietary management of canine urolithiasis. In Practice. 31, 306-312. 
Research, Society and Development, v. 10, n. 12, e501101220876, 2021 (CC BY 4.0) | ISSN 2525-3409 | DOI: http://dx.doi.org/10.33448/rsd-v10i12.20876

Teixeira, A. C. D. J. (2012). Fitoterapia aplicada à prevenção e tratamento de infecções urinárias. Dissertação (Mestre em Ciências Farmacêuticas) Universidade Fernando Pessoa, Porto.

Teixeira, J. B. P.; Santos dos, J. V. (2011). Fitoterápicos e interações medicamentosas. Juiz de Fora: Universidade Federal de Juiz de Fora, Juiz de Fora.

Temoteo, J. L. M. (2017). Avaliação fitoquímica, microbiológica e citotóxica da cavalinha (Equisetum arvense). Dissertação (Pós-graduação em Ciências Farmacêuticas) - Universidade Federal de Alagoas, Maceió.

Veiga, E. C. (2012). Composição química de Echinodorus macrophyllus (kunth) micheli (chapéu-de-couro): uma abordagem teórica. Monografia - Faculdade de Educação e Meio Ambiente (FAEMA), Ariquemes.

Waki, M.; Kogika, M. M. (2015). Urolitíase em Cães e Gatos. In: Tratado de Medicina Interna de Cães e Gatos. Jericó, M.; Neto, J. P. A.; Kogika, M. M. a $^{a}$ edição, Editora Roca. 